\title{
THE MCKENZIE MASSACRE ON BENTINCK ISLAND
}

\section{Roma Kelly and Nicholas Evans}

The Kaiadilt people traditionally lived in the South Wellesley Islands in the Southern Gulf of Carpentaria (see Map). They were extremely isolated and had little or no contact with other Aboriginal groups. Most now live on Mornington Island (traditionally Lardil territory), although attempts to return to the South Wellesleys are now being made.

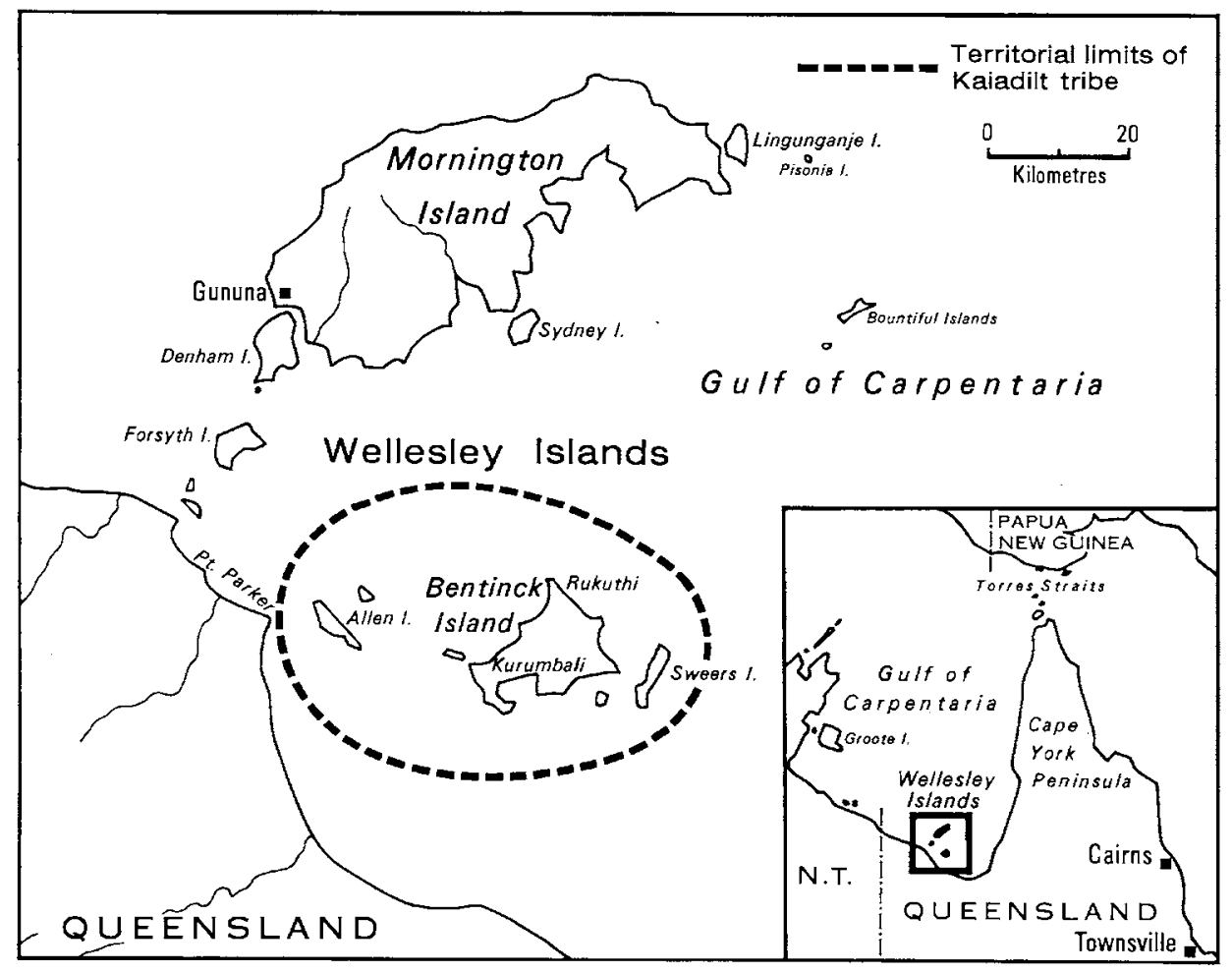

The Wellesley Islands, Southern Gulf of Carpentaria

Nicholas Evans teaches at the School of Australian Linguistics, Batchelor, N.T. He recently submitted his Ph.D. thesis, a grammar of the Kayardild language, at the Australian National University. He is currently producing a Kayardild dictionary and a collection of ethnographic and historical texts. 
The Kaiadilt were afforded their first glimpses of Europeans relatively early, in 1802, when Mathew Flinders met six of them on Allen Island. But they did not emerge fully from their isolation until 1948, when the entire tribe was moved to Mornington Island Mission at Gununa. This made them the last group of coastal Aborigines to come into regular contact with Europeans.

In the intervening period there were various attempts at contact by Government officials, missionaries and would-be settlers. During the 1860 s a settlement, Carnarvon, was established on Sweers Island. For the few years of its occupation the Kaiadilt largely avoided Sweers, although there were some clashes with Europeans there. ${ }^{1}$ Other Europeans to visit Bentinck Island, such as the explorers Captain Stokes (1841) and Captain Pennefather (1880), were carefully avoided, but observed from cover. Dr W.E. Roth, Northern Protector of Aborigines (who visited Bentinck Island in 1901), and his successors Howard (1910) and Bleakley (around 1917) managed only fleeting contacts.

The massacre recounted below occurred around 1918, in conjunction with the only European attempt to occupy Bentinck Island itself. The Kaiadilt tradition does not identify the murderer, and no contemporary record of the massacre exists. Safely beyond the reach of a law that was in any case indifferent to the taking of Aboriginal lives, the murderer's untrammelled excesses went untried and unpunished. The European party almost certainly included one McKenzie, remembered by the wife of an early Mornington Missionary as 'a physically big man, an elderly rugged individual' (Tindale 1962a:266). He had obtained a Government lease to occupy Sweers Island and part of Bentinck Island. Arriving in 1911 'with some sheep and an Aboriginal woman, probably a mainlander from Burketown way" (Memmott 1982:33), he built a hut near the mouth of the Kurumbali estuary on Bentinck Island.

During his short time on Bentinck Island, McKenzie systematically tried to eliminate the Kaiadilt, riding across the island on horseback, and shooting down everyone but the girls he intended to rape. Tindale, who has compiled a detailed genealogy from oral sources, estimates that eleven people were killed (1962b:305) - about 10\% of the Kaiadilt population.

Later he moved to Sweers Island where he ran sheep and goats and established a kiln supplying lime around the Southern Gulf. For a time he employed two Mornington Islanders but 'they soon became disenchanted by the continual diet of goats' heads and livers' (Memmott 1982:34) and flagged down a boat to Mornington Island. McKenzie then obtained other mainland Aborigines as helpers, and a European partner named Nelson. But it is unclear who was with him on Bentinck Island at the time of the massacre.

Roma Kelly, who tells this story, was born about 1917 and heard about McKenzie from her own parents. Her Kaiadilt names are Dibirdibi 'rock cod' and Mambunkingathi 'born at Mambunki. ${ }^{2}$

1 These few paragraphs cannot do justice to the colourful history of the South Wellesleys. Other accounts are in Tindale 1962a and Dymock 1973 but the most thorough is Memmott 1982 .

2 A practical phonemic orthography is employed. The digraphs th and nh represent laminodental stops and nasals respectively; $r d$ and $i n$ retroflexes, $j$ and ny palatais, $I$ a retroflex continuant like $I$ in American English (written $\mathrm{rl}$ before other retroflexes), and $\mathrm{rr}$ an apico-alveolar trill. Vowel length is shown by double letters. There is no voicing contrast, but some stop phonemes are written voiced and others unvoiced, depending on their average phonetic values.

The following abbreviations are used in glosses: ABLative, ACTual (past or present), ALLative, APPRehensive, ASSOCiative, CONSequential, CounTeRFaCTual, DeTransitive (passive or reflexive), 


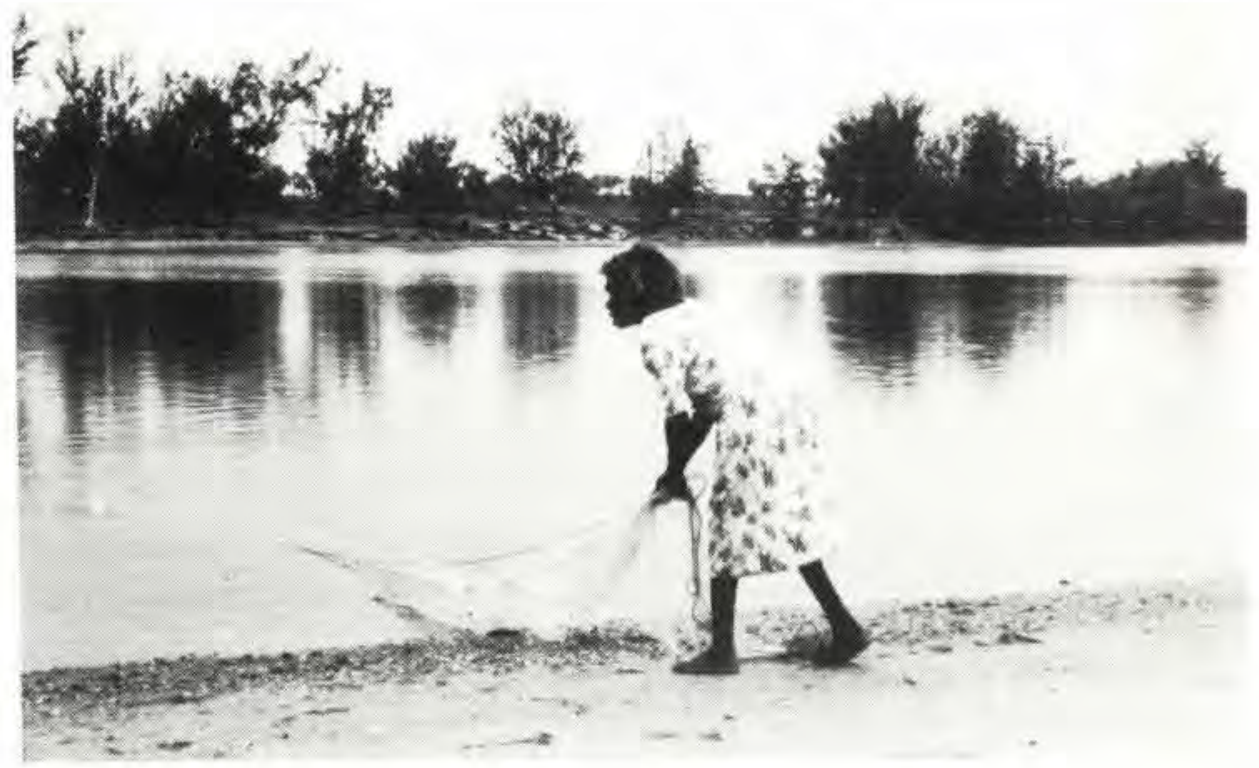

Roma Kelly (photo by Penny Johnson)

(Footnote 2 continued)

DUal, FACtitive, FUTure, INClusive, INCHoative, INTENSifier, INSTRumental, LOCative, Nominalizer, NOMinative, OBJect, PLUral, PRECONdition, PRIOR OBJect (e.g. OBJect of a PRECONdition clause), PRIVative, PROPrietive, UTILitive, Verbal Dative, Verbal Intransitive ALLative, Verbal PURPosive. See Evans 1985 for a description of the grammar. 
1 rukuthi mutha-ya dangka-ya mala-maru-th place name many-OBJ person-OBJ sea-V.D-ACT dathina-wala dog that-LOT(NOM)

2 dog durnwaa-j, dangka-wala jarii-j dog chase-ACT person-LOT(NOM) run away-ACT

3 yuuma-tha mutha-a dangka-a people, drown-ACT many-NOM person-NOM

\section{kunawun}

child(NOM)

4 yuuma-th, dathin-ki thungal-i warna-j, drown-ACT that-OBJ thing-OBJ dislike-ACT dathin-kuru bala-a-nyarr that-PROP shoot-DT-APPR

5 dathin-ki dalurudaluru ${ }^{3}$ warna-j, bayi-wuru that-OBJ gun dislike-ACT fight-PROP jardi-ya warna-j, mob-NOM dislike-ACT

6 yuuma-th. jangka-a dumu-y, jangka-a drown-ACT some-NOM hill-LOC some-NOM walmathi, jangka-a yuuma-th. high up some-NOM drown-ACT

7 kunawuna-nurne-da bardak, marl-da child-ASSOC-STILL belly(NOM) child-ASSOC kunawuna-nurru, yuuma-th. child-ASSOC drown-ACT.

8 kunawuna-wuru bardak, marl-da child-PROP belly(NOM) hand-NOM kunawuna-nurru yuuma-th child-ASSOC drown-ACT
1 At Rukuthi those dogs forced many (Kaiadilt) people into the sea.

2 The dogs chased (them), many people ran away.

3 Lots of people drowned, and children.

4 (They) drowned, (they) didn't like that thing, might get shot by it,

5 didn't like that gun, didn't like that warlike mob (i.e. McKenzie and his gang), and

6 drowned. Some went to the sandhills, some went high up, some drowned.

7 (Women) drowned with children still in their bellies, or leading them by the hand.

8 With children in their bellies and at their hands they drowned.

3 Dal.uru.daluru. though a native Kayardild word analysable as [thundercrack- PROP-REDUP] is always indeclinable. 
9 wulthunga-tha biya-j, mala-ya wiriku-j, turn over-ACT swim-ACT sea-LOC dive-ACT yarki wiriku-j underneath dive-ACT
9. They swam along turning over, dived into the sea, dived under the sea.

10 Far out to sea they drowned and died.

11 They sank dead with their children there way out at sea.

12 Some (stayed) on the crests (of the sand hills), (some) crawled round among the mangroves, in the estuaries.

13 (They) swam about in the estuaries, and drowned among the mangroves.

14 (They) went into the mangrove swamps.

15 They didn't like that thing, that gun thing.

16 That thing, after (they) had eaten and stolen food.

17 (They) stole bullocks, the things that are like many mothers.

ngamathu-wala.

buluka

mother-LOT(NOM) steal-ACT bullock

mother-LOT(NOM)

4 The neologism ngamathuwala does not mean 'many breasts', as one might expect - this would be munirrwala. Rather, the rationale seems to be that a cow supplies as much milk as many mothers. 
bala- $a-j$ jul-bala-a-ja

shoot-DT-ACT INTENS-shoot-DT-ACT

durrwa-yii-j, jinka-a-j

chase-DT-ACT follow-DT-ACT

marndi-i-j, maku-uru marndi-i-j

rob-DT-ACT woman-PROP rob-DT-ACT

20 marngan-da kunawuna thaari-j, nubile-NOM child(NOM) take back-ACT

marngan-da kunawuna kurrka-a-j

nubile-NOM child(NOM) take-DT-ACT

21 jangka-wu maku-ru marndi-i-j, some-PROP woman-PROP rob-DT-ACT

jangka-wu kunawuna-wu marndi-i-j, some-PROP child-PROP rob-DT-ACT

bandarr- $u$

half-PROP

22 kurrka-a-j, marngan-da kunawuna take-DT-ACT nubile-NOM child(NOM)

kurrka-a-j

take-DT-ACT

23 marngan-da kunawuna rar-ung-ku nubile-NOM child(NOM) south-ALL-PROP

thaari-j

take back-ACT

rar-ung-ka kurrka-a-j

south-ALL-NOM take-DT-ACT

25 marngan-ki kunawuna-ya thaari-ja nubile-OBJ child-OBJ take back-ACT

rar-ung-k

south-ALL-NOM
18 (They) were shot at, chased and constantly shot at, followed,

19 robbed, robbed of their women.

20 (McKenzie's men) took the nubile girls back (to their camp), the nubile girls were taken (sexually).

21 (They) were robbed of some of their women, robbed of some of their children, of half (their children).

22 (They) were seized, the nubile girls were seized.

23 (They) took the nubile girls back towards the south.
24 (The girls) were taken southward.

25 (They) took the nubile girls back to the south.

5 McKenzie had a camp at Kurumbali, on the south side of Bentinck Island. One listener remarked here just takem one night altogether, bringim back then might be three day altogether. Lot of woman bin find a child, jangkaa kandukandu, jangka ngumu [some red (half-caste), some black].' 
26 jangka-a yuuma-th, jangka-a some-NOM drown-ACT some-NOM

thungkuwa-y, jangka-a jingka-ri

mangrove-LOC some-NOM swamp-ALL

27 thungkuwa-ya barri-j wirdi-ja

mangrove-LOC crawl-ACT stay-ACT

dakarldi-n-da dakarldii-j

hide-N-NOM hide-ACT

28 kaba-a-nangku jangka-a

find-DT-NEGFUT some-NOM

29 alright jangka-a yuuma-th, jangka-a some-NOM drown-ACT some-NOM

mala-yiwa-tha katharr-iiwa-th,

sea-V.I.ALL-ACT estuary-V.I.ALL-ACT

kunawuna-numu

child-ASSOC(NOM)

30 jangka-a bala-a-j, walmathi

some-NOM shoot-DT-ACT high up

dumu-y,

sandhill-LOC

31 Kunawuna-nurru bala-a-j, jangka-a child-ASSOC(NOM) shoot-DT-ACT some-NOM

bardaka-y,

belly-LOC

32 jangka-a kinyin-d, ${ }^{6}$ rajurri-n-d, some-NOM form-NOM walk about-N-NOM

bala- $a-j$

shoot-DT-ACT

33 tharda-jilarri-ya dangka-a, bala-tha

shoulder-hurt-LOC man-NOM shoot-ACT

wurdiyalaa- $j$

travel about-ACT
26 Some (Kaiadilt) drowned, some (hid) in the mangroves, some (were) scattered about in the swamp.

27 (Some) crawled about in the mangroves, kept themselves hidden away.

28 Some couldn't be found.

29 Yes, some drowned, some went into the sea, some went into the estuaries with their children.

30 Some were shot high up on the sandhills,

31 shot with their babies. Some were (still) in (their) bellies,

32 some already having human form, toddlers, were shot.

33 (That) man's shoulder must have got sore, (he) travelled about shooting,

6 The nour kinyinda means 'visible, extended form' and is appropriate here for a child that has emerged from the invisibility of the womb. 
34 dangka-birrkalii-n-marri, warirr person-feel sorry for-N-PRIV nothing

35 mankin-da dangka-a, warra-waan-d, stranger-NOM person-NOM far-ORIG-NOM maraka warra-wan-da dangka-a CTRFCT stranger-NOM person-NOM

36 maraka mankin-da dangka-a CTRFACT stranger-NOM man-NOM

37 dathin-kuru dulk-uru jardi, that-PROP(NOM) country-PROP mob(NOM)

38 dul-marra-ya dangka-y, country-UTIL-OBJ person-OBJ

39 dulk-uru-ya dangka-ya barnwaa-j country-PROP-OBJ person-OBJ block off-ACT $d u l k-i$ country-OBJ

maraka bi-l-wan-ji dulk-i CTRFACT 3-PLU-POSS-OBJ country-OBJ

41 warra-ja dulk-i wirdi-n-barrwaa-j, go-ACT country-LOC stay-N-block off-ACT kalarr-barrwaa-j, open-block off-ACT

42 mala-maru-tha bala-tha kurulu-th, kurilu-th, sea-V.D-ACT shoot-ACT kill-ACT kill-ACT

ngamathu jarii-j, kanthathu mother(NOM) run away-ACT father(NOM) jarii-j, run away-ACT
34 incapable of feeling sorry, nothing.

35 (They were) strangers, looked like they came from a long way away,

36 looked like strangers.

37 The mob who owned that country,

38 the dulmarra dangkaa (custodians)

39 (they) blocked off the owners from (their own) country.

40 (You would have thought it was) their country.

41 (The Kaiadilt) went about barred from their own country, unable to go out in the open,

42 (McKenzie's mob) shot them out into the sea, and killed, killed.

43 Mothers ran away, fathers ran away,

44 mothers ran away, grandmothers ran away, 
45 jangka-a yuuma-th, jangka-a kurirr, some-NOM drown-ACT some-NOM dead(NOM)

46 kirthan-da wuran-ki diya-j, surreptitiously-NOM food-OBJ eat-ACT buluku-ya diya-j, bullock-OBJ eat-ACT

47 wungi-ja diya-j, bala-a-ja wirdi..., steal-ACT eat-ACT shoot-DT-ACT stay...,

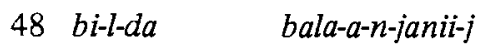

3-PLU-NOM shoot-DT-N-VPURP-ACT

49 bala-a-ju bakii-ju shoot-DT-FUT altogether-FUT

50 jangka-a bala-a-j, jangka-a wirdi-ja some-NOM shoot-DT-ACT some-NOM stay-ACT

\section{birjin-d}

alive-NOM
45 some drowned, some were dead.

46 Behind his back (the Kaiadilt) ate (his) food, ate (his) bullocks,

47 stole and ate (them), they kept getting shot,

48 they were asking to get shot,

49 they would all get shot.

50 Some were shot, some stayed alive. ${ }^{7}$

7 The translation is by Nicholas Evans, incorporating comments by the late Darwin Moodoonuthi.

\section{BIBLIOGRAPHY}

Dymock, J. 'Sweers Island - An Interim Report, Part 1', Anthropological Society of Queensland Newsletter, 1973:2-5.

Evans, N. Kayardild: the language of the Bentinck Islanders of North West Queensland, unpublished Ph.D. dissertation. ANU, 1985.

Memmott, P. 'The South Wellesley Islands and the Kaiadilt. A history and an analysis of the land and its people'. MS, 1982.

Tindale, N.B. 'Geographical knowledge of the Kaiadilt people of Bentinck Island', Records of the South Australian Museum, 14, 1962:252-96.

Tindale, N.B. 'Some population changes among the Kaiadilt people of Bentinck Island'. Records of the South Australian Museum, 14,1962;297-336. 